$\xi=-1$

\title{
Public-Private Partnership: Ghanaian Perspective of Urban Water Supply
}

\author{
Adam Andani Mohammed ${ }^{1 *}$, Abdallah Mpawenimana Saidi ${ }^{2}$ \\ ${ }^{I}$ Faculty of Social Sciences and Humanities, Universiti Malaysia Sarawak, 94300 Kota Samarahan, Sarawak, Malaysia \\ *Corresponding author E-mail:maandani@unimas.my
}

\begin{abstract}
In Ghana, tariff of utilities including water is put below cost recovery levels such that government is unable to cope with the challenges in water supply. As such, the government resorts to private partnership to fund the gaps in the urban water supply in the country. The study adopted an integrative multi-stage critical review of relevant literature on public-private partnership in urban water supply. As such articles published between 2006 and 2017 were selected by specific inclusion criteria. Relevant articles on the topic were identified through references and citations. The paper examines the status and trend of water supply, reforms and management of urban water supply in Ghana. The study found problems like poor water supply system, inadequate human and economic resources as well as poor resource allocations and urban water management.
\end{abstract}

Keywords: Conditionality; Exploitation; Liberalization; Privatization; Urban.

\section{Introduction}

The world's population growth has greater physical and socioeconomic impact which is a great challenge for environmental protection as well as supply and management of water resources. These urbanized communities in developing countries may lack the ability to expand or provide basic services including supply of water. Such situations might pose a keen competition among water resource suppliers and possibility of inadequate protection of water bodies from contamination with domestic and industrial wastes. Studies revealed a decline in the supply of drinking water by two percentage points or more in urban areas of about 10 percent of countries across the globe [1-2]. While the global demand for water has tripled, supply is declining which put a lot of people in water-stressed or water-scarce situation and expected to grow further due to increase in population [3-4]. The water waterstressed is related to the number of people that have to share each unit of water resources. The various demand of water is for industrial use, urban water supply and agriculture. Therefore, sustainable consumption and production are needed to reduce the burden on freshwater and to complement those strategies that operate at the water resource level. The concerns about supply and increase in demand of water are problems for water management in Ghana. The state needs to invest in infrastructure to satisfy numbers of Ghanaians who do not have access to portable water.

The rapid population growth and over-exploitation of raw water resources put the urban population under water-scarce situation. The depletion of resources and the deterioration of general quality make it even more difficult to supply water to urban areas. It is reported that about one fifth of the world's population live where safe drinking water is physically unavailable [5-7]. For instance, most developing countries do not only face scarcity of water but they don't have safe drinking water [2],[8-11]. The general contributing factors to water scarcity in these areas include population growth, usage for agricultural purpose, rising demand due to increasing incomes, rapid urbanization, pollution from agriculture, human and industrial waste as well as poor management of natural resources. Besides, the issues of pollution of water resources are due to people encroaching upon riverbanks which disrupt the water cycle in most urban areas. The access to safe and affordable water for populations in all urban areas in developing countries is featured in the Millennium Development Goals [11-12]. As a result, many developing countries have initiated reforms to provide answers to hurdles blocking access to water and other services to the urban population.

The first world water forum held in Marrakech, Morocco, signaled a growing global concern about the challenges of water resources and supply. Subsequently, international water specialists, politicians, officials and journalists from across the world attended the Second World Water Forum in The Hague, the Netherlands in 2000 to trumpet the serious nature of supply of water resources. Another international water meeting, the Third World Water Forum held in Kyoto, Osaka and Shiga, Japan, in 2003 which about 182 countries attended during which 100 new commitments were made on water, particularly how to supply the entire world and especially developing world safe water [2],[13]. The concern was equitable distribution of water across the population considering the current global water demand of over 4500 cubic kilometers so the challenge was not about availability of adequate water. The distribution of water across the globe is not equal, for instance, the per capita water available to Latin America is higher while Africa, Asia and Europe have far less water per capita. The availability of freshwater is also poorly distributed as there are variations across regions [11],[14-15]. While some countries have about 120,000 cubic meters per capita per year, Kenya has 600 and Jordan 300 cubic meters per capita a year of renewable water resources. This means countries with less than 1000 cubic meter per capita a year are considered water scarce while those with freshwater resources ranging between 1000 and 1600 cubic meters per capita a year are 
water stress especially during drought. It is revealed that many countries are in a stressful situation and some are in water scarcity.

The paper aimed at examining the status and trend of water supply, reforms and management of urban water supply in Ghana.

\section{Method}

As a narrative research, an integrative multi-stage critical review of relevant literature is adopted. As such published between 2006 and 2017 were selected by specific inclusion criteria. Google Scholar was used to search studies on the topic and few articles were identified through references and citations. The articles available in English were selected using keywords and similar terms. The search was limited to studies done between 2006 and 2017, thus a period of ten years. The search was expanded utilizing references and different articles citing to include about 30 studies in the review. The criteria for inclusion were to look for articles and reports published in the last ten years and those that explain urban water supply in developing countries. Besides, articles that involve water quality management, partnership in water supply and improvement of water supply system were included. However, studies done prior to 2006 and those which do not meet the selection criteria were excluded. By identifying some themes from the existing literature, about 28 articles were finally selected and reviewed. All the studies were on developing countries with good analysis of urban water supply.

\section{Results}

The article is designed to document and analyse status and trend of water supply, water reforms and governance in Ghana as below.

\subsection{Status and Trend of Water Supply}

Ghana is a West African country with a diverse ethnic population which shares $2,093 \mathrm{~km}$ of land borders with Co^ted'Ivoire (668 $\mathrm{km})$ to the west, Togo $(877 \mathrm{~km})$ to the east, and Burkina Faso (548 $\mathrm{km}$ ) to the north and Gulf of Guinea and the Atlantic Ocean to the south [16]. The total renewable water resource in Ghana is estimated at $53.2 \mathrm{~km} 3 /$ year out of which $30.3 \mathrm{~km} 3 / \mathrm{yr}$ is produced internally. It is revealed that about billions people of the world's population gain their supply of drinking water from improved sources even though, the unserved population has not changed due to the rapid population growth [2],[7],[17]. The Ghana Water Company (GWCL) is the only regulated utility service provider mandated to supply water to all urban areas in the country. The company is however able to meet the water demands of only 59 percent of urban residents [17]. The focus of the company is centered on pipe distribution through household connection. The annual spending on urban water thirteen years ago was $\$ 17$ million which was far below international standard. For instance, funds needed to meet the Millennium Development Goal of $85 \%$ urban water supply by 2015 was about $\$ 85$ million as at 2005[6].

There has been a drastic change in the trend of water supply, thus from abundance to scarcity due to population growth, urbanization, illegal mining (galamse) and agricultural activities which put much pressure on the existing water bodies. These activities around the urban centers lead to increase in demand for water consumption, water pollution and the eventual climate change [1]. Urban water supply under public management (GWCL) has experienced significant deterioration in Ghana. For instance, it is estimated that only 40 per cent of the urban population is served by the distribution networks [1],[5],[18]. Even though Ghana has enough water resources to satisfy urban water needs, there is still erratic supply or portable water is unavailable in urban areas. The worse affected are often the urban poor due to lack of funding and public networks to these settlements. Besides, the shortages of drinking water are attributed to high levels of line losses of the volume of portable water supplied which account for greater shortages [1]. Generally, inequity in access to drinking water in Ghana is very pronounced. Reports revealed that about 44 per cent of the population in developing countries including Ghana access portable water through household connection or yard tap. Some urban cities in Ghana have already resorted to water rationing distribution strategy to supply water. In this regard, much effort is needed to enhance access to water supply and services [1],[17-18].

\subsection{Water Supply Reforms}

The liberalization of water governance includes policies and reforms, participatory approaches and increasing privatization dominate the water governance circles for decades now [19]. The World Bank and the International Monetary Fund IMF are the brain behind these shifts to promote policies in diverse context. The institutions pushed these water reforms in countries throughout Latin America, Asia and Africa despite the resistance to water privatization or the proposed full cost recovery. For example, the capital city of Ghana, Accra, in the early 1990s witnesses protests against water privatization. This shift proceeded through the specific types of development projects funded by the World Bank and IMF through loan conditionality [5],[19]. Based on this, the government initiated water reforms in 1996 aimed at privatizing drinking water resources in Ghana. The Water Resources Commission WRC was established to control water resources, thus Integrated Water Resource Management IWRM was mandated by the Commission to efficiently, sustainably and equitably manage the water resources. As part of sector reforms, new water law Water Resources Commission Act, Act 522 of 1996- was enacted [20]. However, the implementation of this new law was unsuccessful due to lack of political support and funds. The control of water resources is gradually shifting due donor-pressure to privatize the water supply systems [20]. As such the policies of the donors which were hotly debated instigated the privatization of urban water supply in the urban areas.

The supply of adequate water is covered in the Ghana Poverty Reduction Strategy I and II (GPRSI and GPRSII) aimed at reducing human deprivation, promoting human rights to achieve sustainable growth. It is revealed that urban water supply coverage is still low despite the efforts to enhance water supply as part of poverty reduction. The Ghana Water and Sewerage Corporation GWSC adopted a five-year water sector development plan in 1983 under the Economic Recovery Program ERP sponsored by the World Bank. This plan aimed at manpower development, rehabilitation and expansion of existing service and decentralization of water supply [5],[17]. Based on this plan, GWSC and Community Water and Sanitation Division were mandated to handle provision of water in urban and rural areas. The restructuring was in preparation for private participation in urban water supply so institutions were set up. In the process, the GWSC operating urban water was changed to Ghana Water Company Limited GWCL, a semiautonomous public agency [6]. Besides, Community Water and Sanitation Agency (CWSA) and Water Resources Commission (WRC) were set up to facilitate water supply and see to the environmentally sound management of water resources in Ghana [5],[18],[20]. In terms of regulations, the Public Utility Regulatory Commission (PURC) was established to ensure quality utility services and to coordinate the activities of the various institutions to abide by government policies in the water sector. The Ministry of Works and Housing was mandated through a directorate to coordinate activities in the water sector.

\subsection{Urban Water Governance}

The key factor in addressing water related problems emerged in the late twentieth century and emphasized on governance. The impression is that technology and infrastructure are insufficient to address persistent water management problems. As such, the United Nations indicate that water crisis is essentially a crisis of governance which leads to social, economic and political challenges 
on how societies govern water more effectively [5],[11]. Initially, water challenges in Ghana were perceived as local issues so governance efforts emphasized at the local levels. However, the domains of these challenges need more comprehensive and coordinated efforts. Water governance is the development and implementation of norms, principles, rules, incentives, informative tools and infrastructure to promote a change in the behavior of actors at the global level [21]. Thus, water governance in Ghana focuses on the processes of national and international cooperation from formal and informal institutions like the World Bank, IMF and nongovernmental organizations. These processes inform the way challenges are tackled from state levels to civil society organizations and to suggest opportunities to meet the objectives of urban water supply. The issue of water governance facilitates interaction and dialogue among key players in Ghana to inform the development of solutions to urban water problems.

The management of urban water reform through World Bank projects became necessary in Ghana due to the erratic water supply and acute water shortages across the country. The idea of private participation is the possibility of infusing into the system with technical knowhow, efficient and effective management and capital for infrastructure development in the urban water system. It was these ideas that led to the 20-year lease agreement signed with Azurix Corporation, a subsidiary of Enron Corporation to operate urban water systems in Ghana [6]. Right from the onset of the reforms, civil society groups were against separating the management of urban water networks from the rural water supply system in the name of profit [5-6]. As part of the urban water reforms, Ghana signed a 20-year lease contract with Azurix Corporation in 2000 to supply water to the urban centers in Ghana. Despite the opposition from civil society groups and allegation of bribery against the parties involved, the contract fell through. Based on this, discussions to get a partner for a private participation in the urban water supply had to start afresh. The Ghana Water Company Limited (GWCL) in 2006 signed a 5-year management contract with Vitens Rand Water Services BV of Netherlands and South Africa and their subsidiary in Ghana, Aqua Vitens Rand Limited (AVRL) [6], [22].

\section{Discussion}

The rationale for private participation is due insufficient state financial resources to undertake the needed investments for large scale water supply projects. The anticipation of improved efficiency, cost effectiveness and innovation in water services to counter the growing populations and rapid urbanization is enormous. In support of this, studies state that private participation in water supply is service-based models that attract skills and management expertise from the private sector for efficiency and to optimise costs or financed-based where innovative skills and capital are used to design modern water infrastructure assets with little or no public financial commitments [1],[5],[23]. The private participation in water supply project is shaped by social, economic and political conditions of the country [24-25]. For the civil society, water is a necessity of life like food, clothing or housing which concerns national security and should not be handled by private individuals. The state, donors and some agencies who propose private participation in water supply demand payment of realistic tariffs from customers for efficient and effective delivery. On the other hand, those against privatization indicate that water is a public good and not a private commodity to be traded for profit because access to water is a fundamental human right. Studies suggest that the state is supposed to provide water at affordable price for the people either urban rich or poor [6],[22]. The water privatization is viewed as some sort of death sentences for the majority of the urban poor in Ghana who cannot pay the realistic tariffs proposed. Unfortunately, the groups that formed the antiprivatization coalition lack resources to contract consultants to provide research information to support their positions in relation to the policy [6],[25]. Better still, the mass retrenchment of labor that follows privatization of state owned companies has been the fear of the civil society groups.

The collapse of state spending power led to proposals for reforms as conditions were susceptible to external pressures especially among the international financial institutions like the International Monetary Fund and World Bank. Then prevailing economic crisis and donor influence generated a need for change that necessitated the reform in Ghana [6],[20]. It can be infer that the internal and external actors instigated this policy shift considering the role played by the multilateral and bilateral institutions considering pressure exerted in the process because they serve as advisors and financial sponsors of reforms. The influence of donors in reforms is associated and concern with stabilization of the economy which is handled by cutting the expenditure of the civil service, removal of subsidies and privatized monopoly marketing boards. It is corroborated that the IMF and World Bank have continuously pressurized the country on the issues of reforms [6],[26]. The reform was adopted to address the problems of water supply confronting urban dwellers. Recent studies have it that private partnership in water supply is a preferred means to procure public infrastructure assets and services [24-26]. For effective implementation of policies, government agencies engage the services of consultants to produce research to support their goals

The new laws and policies changed the way water rights are legally treated in Ghana. As revealed, it vested the ownership of water resources in the state and abolished the customary ownership of water by stools, communities, families and individuals. However, customary laws and water rights granted under common law are still officially recognized and continued to reign over water use and management practices throughout the country. As a result, monitoring of water resources is through the implementation of the water use regulations at the local level through the local authorities. However, uses of water that exceed basic water abstraction are to be billed and therefore need permission from the mandatory body [6],[20]. In this case, the Water Regulatory Commission mandated to management water resources in the country takes control over the equity and ecology and thus issue water-use permits and water use tariffs. However, the water reforms are problematic due to lack of authority, finance and human capacities to engage in the local implementation of water use regulations. Therefore, the monitoring and allocation of water use rights are supposed to be undertaken by local governments with the help of traditional authorities. In the course of these reforms, the need to develop a supervisory body and laws for the water sector because investors need security for their investments [27-28]. Therefore, the enactment of a new water law has created the Water Rights Commission which vesting water rights in the state. The state was expected to set up independent public agencies to operate the urban water supply system with private sector principles to ensure efficiency and effectiveness.

\section{Conclusion}

In the face of urbanization, states are unable to extend water supply to match urban population growth. The inadequate investment in water infrastructure over the past decades restricted access to water by the urban population. This water scarcity results in further marginalization of living conditions and generates high levels of morbidity in the poorest urban areas. Water rationing and low quality storage systems leave the population without adequate potable water. As a result, entrepreneurial water vendors stepped in to supply water in three general delivery modes like the tank supplied by trucks, from borehole and packaged as sachets with varying degrees of filtration. The transition to a new water reform has been only partial and incomplete since the decentralization and sustainability initiatives of the law is dysfunctional due to lack of political will to implement decentralization agenda. 


\section{References}

[1] Albert PCC, Ernest EA (2013), The private sector's involvement in the water industry of Ghana. Journal of Engineering, Design and Technology 11(3), 251 - 275

[2] Bartram J, Brocklehurst C, Fisher MB, Luyendijk R, Hossain R, Wardlaw T, Gordon B (2014), Global monitoring of water supply and sanitation: history, methods and future challenges. International Journal of Environmental Research and Public Health 11(8), 8137-8165.

[3] Hanjra MA, Qureshi ME (2010), Global water crisis and future food security in an era of climate change. Food Policy 35(5), 365-377.

[4] Nilsson D (2016), The unseeing state: how ideals of modernity have undermined innovation in Africa's urban water systems. NTM Zeitschrift für Geschichte der Wissenschaften, Technik und Medizin 24(4), 481-510.

[5] Bohman A (2010), Framing the water and sanitation challenge: A history of urban water supply and sanitation in Ghana 1909-2005 (Doctoral dissertation, Department of Economic History, Umeå University).

[6] Ainuson K (2009), An advocacy coalition approach to water policy change in Ghana: A look at belief systems and policy oriented learning. Journal of African Studies and Development 1(2), 16.

[7] Cohen B (2006), Urbanization in developing countries: curren trends, future projections, and key challenges for sustainability. Technology in Society 28(1), 63-80.

[8] Zhong L, Mol AP, Fu T (2008), Public-private partnerships in China's urban water sector. Environmental Management 41(6), 863 877.

[9] World Health Organization (2015), Progress on Sanitation and Drinking Water: 2015 Update and MDG Assessment.

[10] Wilder M (2010), Water governance in Mexico: political and economic aperatures and a shifting state-citizen relationship. Ecology and Society 15(2)

[11] Gleick PH (Ed.) (2014), The World's Water Volume 8: The Biennial Report on Freshwater Resources. Island Press.

[12] Yu W, Wardrop NA, Bain RE, Lin Y, Zhang C, Wright JA (2016), A global perspective on drinking-water and sanitation classification: an evaluation of census content. PloS one 11(3), e0151645.

[13] Gupta J, Akhmouch A, Cosgrove W, Hurwitz Z, Maestu J, Ünver O (2013), Policymakers' reflections on water governance issues. Ecology and Society 18(1).

[14] Ellis H, Schoenberger E (2017), On the identification of associations between five World Health Organization water, sanitation and hygiene phenotypes and six predictors in low and middle-income countries. PloS one 12(1), e0170451.

[15] Chan PCA, Effah Ameyaw E (2013), The private sector's involvement in the water industry of Ghana. Journal of Engineering, Design and Technology 11(3), 251-275.

[16] Sosuh, MM (2011), Border security in Ghana: challenges and prospects. KAIPTC Occasional Paper No. 32, Accra.

[17] Ainuson KG (2010), Urban water politics and water security in disadvantaged urban communities in Ghana. African Studies Quarterly 11(4), 59

[18] Stoler,J, Weeks JR, Fink G (2012), Sachet drinking water in Ghana's Accra-Tema metropolitan area: past, present, and future. Journal of Water Sanitation and Hygiene for Development 2(4), 223 240.

[19] Harris LM, Roa-García MC (2013), Recent waves of water governance: constitutional reform and resistance to neoliberalization in Latin America (1990-2012). Geoforum 50, 20-30.

[20] Laube W (2007), The promise and perils of water reforms: Perspectives from Northern Ghana. Africa Spectrum, 419-437.

[21] Pahl-Wostl C, Holtz G, Kastens B, Knieper C (2010), Analyzing complex water governance regimes: the management and transition framework. Environmental Science \& Policy 13(7), 571-581.

[22] Stoler J, Fink G, Weeks JR, Oto, RA, Ampofo JA, Hill AG (2012), When urban taps run dry: sachet water consumption and health effects in low income neighborhoods of Accra, Ghana. Health \& Place 18(2), 250-262.

[23] Kayaga S (2008), Public-private delivery of urban water services in Africa. Proceedings of Civil Engineers: Management, Procurement and Law 160(4), 147-155.

[24] Menard C, Peeroo A (2011), Liberalization in the water sector: three leading models. In: Kunneke R, Finger M (Eds), Handbook of Liberalization, E. Elgar, Cheltenham, Chapter 18, 310-327.

[25] Effah Ameyaw E, Chan AP (2013), Identifying public-private partnership (PPP) risks in managing water supply projects in Ghana. Journal of Facilities Management 11(2), 152-182.
[26] Ernest EA, Albert PCC (2016), Critical success factors for publicprivate partnership in water supply projects. Facilities $34(3 / 4), 124$ -160 .

[27] Atampugre G, Botchway DVN, Esia-Donkoh K, Kendie S (2016), Ecological modernization and water resource management: A critique of institutional transitions in Ghana. GeoJournal 81(3), 367 378 .

[28] Mohammed AK (2016), An assessment of the impact of local government fragmentation in Ghana. Public Organization Review 16(1), 117-138. 